\title{
Verification of Soil Test Based Phosphorous Calibration Study for Bread Wheat (Triticum Aestivum L.) Production in Horo District, Oromia Regional State, Ethiopia
}

\author{
Temesgen Chimdessa*, Chalsissa Takele \\ Oromia Agricultural Research Institute, Nekemte Soil Research Center, Oromia, Ethiopia \\ Email address: \\ Temesgenchimdessa468@gmail.com (T. Chimdessa),chalsissat@gmail.com (C. Takele) \\ ${ }^{*}$ Corresponding author
}

To cite this article:

Temesgen Chimdessa, Chalsissa Takele. Verification of Soil Test Based Phosphorous Calibration Study for Bread Wheat (Triticum Aestivum L.) Production in Horo District, Oromia Regional State, Ethiopia. Advances in Biochemistry. Vol. 8, No. 3, 2020, pp. 52-56. doi: $10.11648 /$ j.ab.20200803.12

Received: September 23, 2020; Accepted: October 9, 2020; Published: October 26, 2020

\begin{abstract}
On-farm verification trial of soil test based crop response phosphorous calibration study for bread wheat production was conducted in 2019/20 main cropping season in the Horo District of the Horo Guduru Wollega Zone. The trial was initiated to verify phosphorus critical level and requirement factor for bread wheat production in Horo District. The treatments were the control (without phosphorus fertilizer), farmers practice (blanket recommendation) and soil test based recommended phosphorus fertilizer rate (RR). The trial was conducted on six farmers' field across the district. Plot size was $10 \mathrm{~m} * 10 \mathrm{~m}$. Soil data before planting and yield data were collected throughout the trial. Soil reaction $\mathrm{pH}\left(\mathrm{H}_{2} \mathrm{O}\right)$ of all the sites ranged from 4.73 to 5.42 and available $\mathrm{P}$ ranges from 1.4 to $12.6 \mathrm{ppm}$. Soil acidity of the experimental sites were amended with lime. Bread wheat grain and biomass yield $(\mathrm{kg} / \mathrm{ha})$ were high and significantly $(\mathrm{p}<0.01)$ affected by different fertilizer rates used as treatments. The highest grain yield $(2875 \mathrm{~kg} / \mathrm{ha})$ was resulted with soil test based phosphorus fertilizer rate recommendation. Economically optimum N (46 kg/ha), critical level phosphorus (10 ppm) and phosphorus requirement factor $(11.03 \mathrm{~kg} / \mathrm{ha})$ for bread wheat production in the district were gained and recommended during the calibration study. It was significantly higher than the grain yield gained from the farmers' practice $(2119.4 \mathrm{~kg} / \mathrm{ha})$ and control/without phosphorus fertilizer $(1647.2 \mathrm{~kg} / \mathrm{ha})$. Similarly, soil test based phosphorus fertilizer rate recommendation was economically optimum and feasible for bread wheat production in the district.
\end{abstract}

Keywords: Bread Wheat, Horo, Phosphorus Fertilizer, Recommendation

\section{Introduction}

Wheat with production area of about 1.66 million hectares is one of the most important cereal food crops cultivated in Ethiopia, ranking fourth after teff (Eragrostis tef), maize (Zea mays) and sorghum (Sorghum bicolor) in area coverage [4]. Traditionally, wheat grains are used to prepare household bread, beverage and pancake. It is also processed in factories to produce flour for commercial production of bread for consumers in cities and towns. Despite, the population of Ethiopia is currently growing at a faster rate and demands also proportional for agricultural products.

On the other hand, growth in food production is not in equal footings with population pressure. Strengthening food production capability of the country by wisely exploiting its existing human and natural resources is critical option to avert the existing situation. However, soil fertility depletion and soil quality decline are the main constraints affecting the yield and sustainability of crop production in Ethiopia. The annual per-hectare net loss of nutrients is estimated to be at least $40 \mathrm{~kg} \mathrm{~N}, 6.6 \mathrm{~kg} \mathrm{P}$ and $33.2 \mathrm{~kg} \mathrm{~K} \mathrm{[14].} \mathrm{The} \mathrm{identification}$ of the proper fertilizer mix is beneficial at the macroeconomic level by improving the efficiency of fertilizer procurement and resource allocation. It is generally understood that crop response to fertilizer inevitably declines, if nutrient applications are continually unbalanced. But, if harvested nutrients are replaced, intensive agricultural systems can be sustained indefinitely, provided that measures 
are taken to halt soil erosion and to minimize detrimental changes in soil $\mathrm{pH}$.

In Ethiopia, century-long, low-input agricultural production systems and poor agronomic management practices, limited awareness of communities and absence of proper land-use policies have aggravated soil fertility degradation [1]. Phosphorous is the most yield limiting of soil-supplied elements, and soil P tends to decline when soils are used for agriculture (David and David, 2012). Studies have demonstrated that Nitisol areas in Ethiopia are marginally to severely deficient in P [3 and 12]. In Ethiopia, the blanket recommendations that are presently in use all over the country were issued several years ago, which may not be suitable for the current production systems [18]. Since the spatial and temporal fertility variations in soils were not considered, farmers have been applying the same $\mathrm{P}$ fertilizer rate to their fields regardless of soil fertility differences.

Soil tests are designed to help farmers predict the available nutrient status of their soils. Once the existing nutrient levels are established, producers can use the data to best manage what nutrients are applied, decide the application rate and make decisions concerning the profitability of their operations [2]. However, local assessments for the soil $\mathrm{P}$ critical levels and soil $\mathrm{P}$ requirement factors even for the major crops of the country are negligible. Currently, soil fertility research improvement is agreed with respect to site specific fertilizer recommendation in the country [8].

Previously, soil test crop response based phosphorus calibration on bread wheat study was carried out in Horro district and the critical phosphorus value has to be verified to approve the acceptance of the technology at farmers' level. Therefore, this project must address the need for reliable soil nutrient calibration/ correlation data and verify the economic profitability of the technology comparing with farmers practice and verify the critical levels of $\mathrm{P}$ calibrated previously.

\section{Materials and Methods}

\subsection{Description of the Study Area}

Horo is situated at latitude: $1,042,726 \mathrm{~N}$ to $1,091,814 \mathrm{~N}$; Longitude $270,000 \mathrm{E}$ to $316,199 \mathrm{E}$ and an altitude ranging from 1449-3147 m above sea level; in Horo-Guduru Wollega Zone of the Oromia regional state, Ethiopia (Figure 1.). The terrain is generally undulating to rolling plains. The area is characterized by a mono-modal rainfall pattern. The mean monthly rainfall ranges from 12.8 to $343.8 \mathrm{~mm}$, and mean monthly temperature is 17.23 -to $22.9^{\circ} \mathrm{C}$. The major soil types are generally described as Nitisols [9].

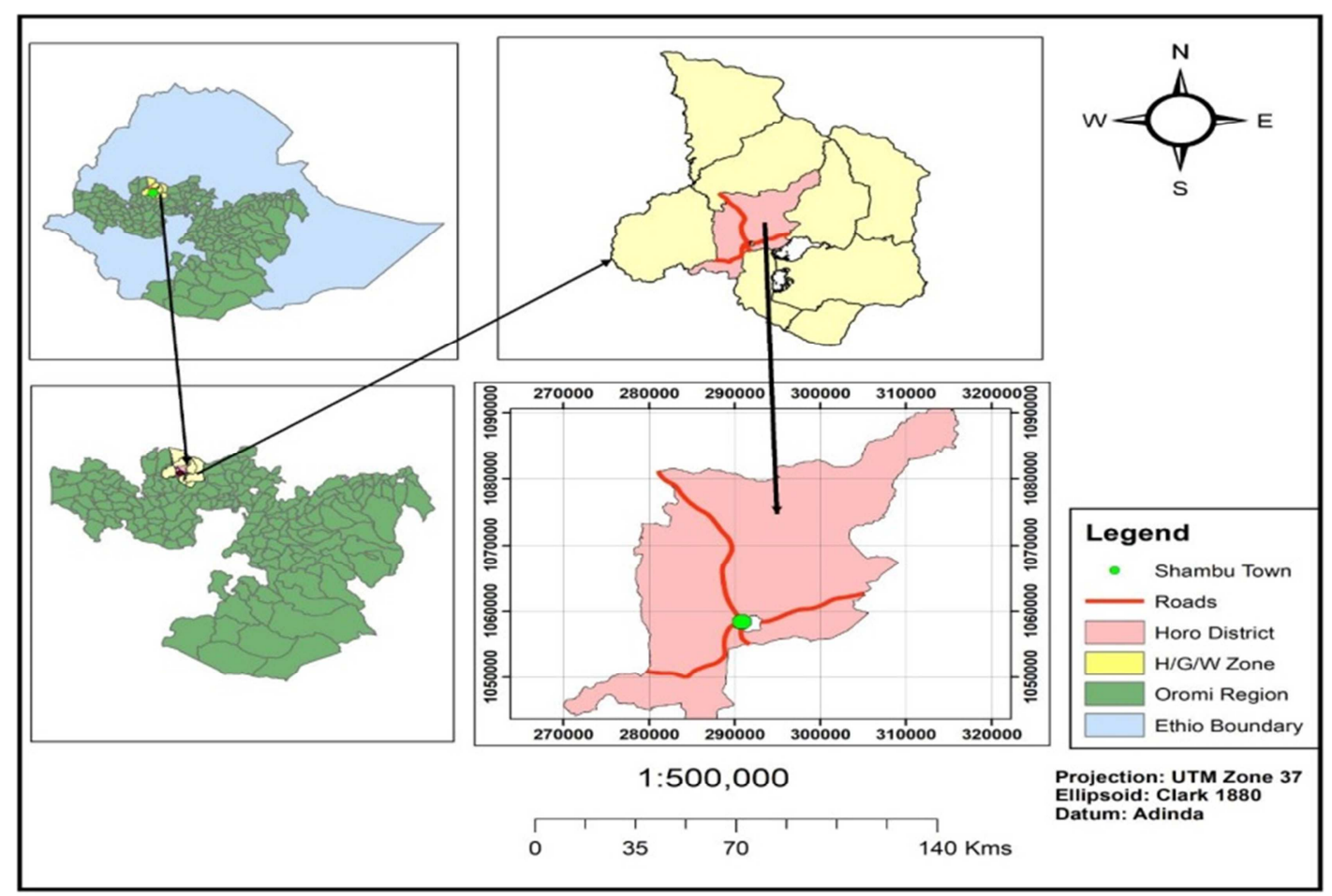

Figure 1. Location map of Horo District, Oromia, Ethiopia.

\subsection{Experimental Design and Procedures}

The study was conducted on farmers' fields across the District. Six farmers were selected purposively based on their willing, wealthy and initial soil P-value. Improved wheat variety Dendea was used at $150 \mathrm{~kg} /$ ha seeds rate with $20 \mathrm{~cm}$ inter row spacing were sown. Phosphorus fertilization rate was given according to the formula developed, $\mathrm{P}(\mathrm{kg} / \mathrm{ha})=(\mathrm{P}$ critical-P initial)* Prf. This recommendation was compared with farmers practice (blanket recommendation) and control. Urea and DAP were used as the source of $\mathrm{N}$ and $\mathrm{P}$, respectively. For verification purpose the experiment was laid out in randomized complete block design that was replicated 
over farmers. The treatment considered were calculated $\mathrm{P}$ (Rate of $\mathrm{P}$ fertilizer to be applied $=($ Critical $\mathrm{P}$ conc.-initial $\mathrm{P}$ values $) * \mathrm{P}$ requirement factor whereas $\mathrm{Pc}=10 \mathrm{ppm}$, and $\mathrm{Pf}=$ 11.02) with determined optimum N (46 kg), Farmer practice /blanket recommendation (100 kg DAP and $100 \mathrm{~kg}$ Urea) and control (without fertilizer). Nitrogen was applied in the form of urea in two splits (1/2 at planting and $1 / 2$ at mid-stage). Plot size was $10 \mathrm{~m}$ x $10 \mathrm{~m}$ and there was $1 \mathrm{~m}$ between blocks and $0.5 \mathrm{~m}$ between plots. Composite soil samples were collected at a depth of $20 \mathrm{~cm}$ from each selected farmers' field to determine $\mathrm{pH}\left(\mathrm{H}_{2} \mathrm{O}\right)$ and available $\mathrm{P}$ (Olsen method). The grain data and biomass yield of the crops were collected. Grain yield and biomass yield recorded on the plot bases were converted to $\mathrm{kg} \mathrm{ha}^{-1}$ for statistical analysis.

\subsection{Economic Analysis}

Partial budget analysis was done to determine economic feasibility of recommended fertilizer $\mathrm{P}$ for bread wheat production around the study areas following procedures described as [5]. The mean grain and biomass yield data of wheat were employed in the analyses. Furthermore, the grain and biomass yield obtained from each treatment were adjusted down by $10 \%$ in order to narrow down the possible yield gap that may happen due to difference in field management. The average prices of relevant inputs required to do the partial budget analyses were collected from different sources.

\subsection{Data Management and Analysis}

Data were subject to analysis of variance (General Linear Model (GLM) procedure) using SAS software [15] to test treatments effect on crop growth and yield parameters. Means of treatment effects were separated using the Duncan's Multiple Range Test (DMRT) comparison at $\mathrm{p} \leq$ 0.05 .

\section{Result and Discussion}

\subsection{Soil pH and Available Phosphorus}

The soil reaction of the experimental sites before planting ranged from 4.73-5.42 (table 1). Accordingly, the soils were strongly to extremely acidic in reaction [17]. According to [13], the suitable $\mathrm{pH}$ range for wheat crop is between 5.5 and 7.0. Continuous cultivation and long-term application of inorganic fertilizers led to low soil $\mathrm{pH}$ and aggravated the losses of basic cations from highly weathered soils. Moreover, the acidic nature with low soil $\mathrm{pH}$ obtained from the whole sites may be attributed to the fact that the soils were derived from weathering of acidic igneous granites and leaching of basic cations such as $\mathrm{K}, \mathrm{Ca}$ and $\mathrm{Mg}$ from the surface soil [10].

The maximum and minimum values of available $\mathrm{P}$ were 37.88 and $2.31 \mathrm{ppm}$, respectively (table 1). Available phosphorus of most samples fall under low category according to the critical level set by EthioSIS [11]. Generally, the available $\mathrm{P}$ status of the soils in the study area are low, even below the critical level indicating that soil $\mathrm{P}$ infertility is among the factors that are highly limiting the productivity of the soils. This shows the need for external application of phosphorus fertilizer sources for good crop growth and yield.

Table 1. Initial available soil phosphorus and soil pH.

\begin{tabular}{lll}
\hline Sites & Soil $\mathbf{~ p H}\left(\mathbf{H}_{\mathbf{2}} \mathbf{O}\right)$ & Available $\mathbf{P}(\mathbf{p p m})$ \\
\hline Site 1 & 4.73 & 7.04 \\
Site 2 & 5.31 & 2.31 \\
Site 3 & 5.42 & 7.29 \\
Site 4 & 5.09 & 37.88 \\
Site 5 & 5.4 & 19.25 \\
Site 6 & 5.27 & 6.98 \\
\hline
\end{tabular}

\subsection{Biomass and Grain Yield of Bread Wheat}

The analysis of variance showed that the recorded biomass yield of bread was significantly affected $(\mathrm{p}<0.001)$ only by the application of soil test crop response-based phosphorus fertilizer application. The highest mean grain yield (2875 $\mathrm{kg} / \mathrm{ha}$ ) was recorded with the soil test crop response-based fertilizer recommendation treatment (table 1) which was significantly higher than the farmer practice $(2119.4 \mathrm{~kg} / \mathrm{ha})$. The results of this study are consistent with findings of [7] who reported that the highest grain yield was recorded under application of soil $\mathrm{p}$ calibration.

Table 2. Mean grain and biomass yield $(\mathrm{kg} / \mathrm{ha})$ of bread wheat as influenced by different fertilizer application at Horo district.

\begin{tabular}{lll}
\hline Treatments & Grain Yield (kg/ha) & Biomass (kg/ha) \\
\hline RR & $2875.0^{\mathrm{a}}$ & $8330.6^{\mathrm{a}}$ \\
FP & $2119.4^{\mathrm{b}}$ & $6625.0^{\mathrm{b}}$ \\
C & $1647.2^{\mathrm{b}}$ & $6036.1^{\mathrm{b}}$ \\
Significance & $* * *$ & $* * *$ \\
LSD (5\%) & 536.03 & 1543.4 \\
CV & 12.12 & 1.04 \\
\hline
\end{tabular}

RR: Recommended rate; FP: Farmers practice/blanket recommendation; C: Control

\subsection{Economic Analysis}

The results of partial budget analyses data of $\mathrm{S}$ fertilizers across two soils are summarized in table 3. Accordingly, all treatments produced higher and positive net benefit (NB) relative to the control treatment in both sites, indicating that feasibility of fertilizer application for wheat production in the study area.

The marginal rate of return of the non dominated treatments in table 3 shows that $149 \mathrm{~kg}$ /ha of soil test crop response-based $\mathrm{P}$ fertilizer (RR) treatments provided a positive marginal rate of return of 3501.6. According to [5], on the farm-economic analysis of major cereals training reported that MRR that range from $50 \%$ to $100 \%$ was the minimum recommended rate in most agricultural production and it is better when the MRR was $>100 \%$. Treatments that receive recommended rate of fertilizer was received 3501.6 which indicates that by investing one birr on these treatments, there was high rate of returns which was 35.02 birr benefit without including costs that not vary among treatments.

The marginal rate of return (MRR) was found to be 
$3501.6 \%$ for soil test-based fertilizer rate and $1970.7 \%$ for farmer practice (table 3 ). The economic analysis showed that the highest net income (27649.3ETB) was obtained from soil test based recommended treatments. So, those treatments that receive recommended fertilizer record the highest MRR acceptance range and so, farmers use this soil test crop response-based fertilizer application than other treatments which is cost effective and economically feasible.

Table 3. Partial budget analysis for verification of bread wheat at Horo District.

\begin{tabular}{|c|c|c|c|c|c|c|c|c|c|c|c|}
\hline Treatments & $\begin{array}{l}\text { UREA } \\
\text { (qt/ha) }\end{array}$ & $\begin{array}{l}\text { DAP } \\
\text { (Qt/ha) }\end{array}$ & $\begin{array}{l}\text { GY } \\
\text { (Qt/ha) }\end{array}$ & $\begin{array}{l}\text { AGY } \\
\text { (Qt/ha) }\end{array}$ & $\begin{array}{l}\text { GFB } \\
\text { (ETB/ha) }\end{array}$ & $\begin{array}{l}\text { FC } \\
\text { (birr/ha) }\end{array}$ & $\begin{array}{l}\text { TSC } \\
\text { (birr/ha) }\end{array}$ & $\begin{array}{l}\text { HBC } \\
\text { (birr/ha) }\end{array}$ & $\begin{array}{l}\text { TVC } \\
\text { (birr/ha) }\end{array}$ & $\begin{array}{l}\text { NB } \\
\text { (birr/ha) }\end{array}$ & $\begin{array}{l}\text { MRR } \\
(\%)\end{array}$ \\
\hline $\mathrm{C}$ & 1 & 0.00 & 16.472 & 15.5 & 18566.4 & 2804.6 & 1547.2 & 773.6 & 5125.4 & 13441.0 & \\
\hline FP & 0.6087 & 1.00 & 21.194 & 20.2 & 24232.8 & 2369.9 & 2019.4 & 1009.7 & 5399.0 & 18833.8 & 1970.7 \\
\hline RR & 0.4158 & 1.49 & 28.75 & 27.8 & 33300.0 & 1488.3 & 2775.0 & 1387.5 & 5650.8 & 27649.3 & 3501.6 \\
\hline
\end{tabular}

Where: $\mathrm{qt}=$ Quintal; ha $=$ Hectare; $\mathrm{GY}=$ Grain yield; $\mathrm{AGY}=$ Adjusted Grain Yield; GFB $=$ Gross field benefit ETB $=$ Ethiopian birr; FC $=$ Fertilizer cost; $\mathrm{TSC}=$ Total Service cost $\mathrm{HBC}=$ Harvesting and bagging cost TVC $=$ Total variable cost; $\mathrm{NB}=$ Net benefit; $\mathrm{MRR}=$ Marginal rate of return; $\mathrm{C}=\mathrm{Control}$ (without $\mathrm{P}$ fertilizers); $\mathrm{FP}=$ Farmers practiced fertilizer rate and $\mathrm{RR}=$ Soil test based Fertilizer rate; $\mathrm{FC}=$ Fertilizer cost and DAP $=$ Diammonium Phosphate.

\section{Conclusion and Recommendation}

In Ethiopia, the blanket recommendations that are presently in use all over the country were issued several years ago, which may not be suitable for the current production. Since the spatial and temporal fertility variations in soils were not considered, farmers have been applying the same $\mathrm{P}$ fertilizer rate to their fields regardless of soil fertility differences. Based on the results of this study, it is generally concluded that, soil test crop response-based fertilizer application ( $\mathrm{P}$ application) gave consistently high grain yield of bread wheat the study area showing that the soil of the study area is deficient in $\mathrm{P}$ content.

Since by applying recommended rate of $\mathrm{P}$ and optimum urea fertilizer application rate, yield of bread wheat could be increased by $36 \%$ over the blanket fertilizer recommendation of DAP and urea. The implication was that application of fertilizer based on site specific soil test crop response based is useful to attain the demand of bread wheat for the current population growth by boosting yield by more than $50 \%$. Result of economic analysis also showed that recommended rate of fertilizer with site specific recommendation is ideal to obtain higher yield in the study area.

\section{Acknowledgements}

First and foremost, we would like to thank Almighty God for blessing us with invaluable gifts of health, strength, patience and protection to start and complete this study. Secondly, the authors would like to thank Agricultural growth program project for financial support and Nekemte Soil Research Center for providing all the necessary facilities needed for the activity.

\section{References}

[1] Agegnehu, G. and Bekele, T., 2005. On-farm integrated soil fertility management in wheat on Nitisols of central Ethiopian highlands. Ethiopian Journal of Natural Resources, 7 (2), pp. 141-155.
[2] Agegnehu, G. and B. Lakew, 2013. Soil test phosphorous calibration for malt barley production on Nitisols of Ethiopian highlands. Trop. Agric. 90: 177-187.

[3] Bekele, T., Ashagrie, A., Tulema, B., and G. Gebre Kidan, 1996. "Soil fertility management in Barley." In Barley research in Ethiopia: past work and future prospects edited by H. Gebre, van J. Leur, 92-99. IAR/ICARDA, Addis Ababa, Ethiopia.

[4] CSA (Central Statistical Agency). 2016. Agricultural sample survey report on area and production of major crops: Private peasant holdings in meher season of 2015/2016 (Vol. I, No. 584). CSA, Addis Abeba, Ethiopia.

[5] CIMMYT (International Maize and Wheat Improvement Center). 1998. From agronomic data to farmer recommendations: $A n$ economic workbook. CIMMYT, Mexico.

[6] David, M. E. and J. T. David, 2012. Modeling an Improvement in phosphorous utilization in Tropical Agriculture. Journal of Sustainable Agriculture, 36: 18-35.

[7] Dejene Getahun, Dereje Girma, Abreham Feyisa, Ajema Lemma, and Lello Dejene. 2020. Verification of Soil Test Crop Response Based Phosphorus Recommendation on Bread Wheat (Triticum Aestivum L.) in Yaya Gulele District of North Shewa Zone, Oromia. International Journal of Applied Agricultural Sciences. Vol. 6, No. 3, pp. 52-56. doi: 10.11648/j.ijaas.20200603.14.

[8] EthioSIS (Ethiopian Soil Information System), 2015. http://www.ata.gov.et/highlighteddeliverables/ethiopiansoilinformation-system-ethiosis/. Accessed 15 June 2020.

[9] FAO (Food and Agriculture Organization), 1990. www.fao.org/ag/AGP/AGPC /doc/counprof/ ethiopia/ethiopia.htm. Accessed 20 March, 2020.

[10] Frossard, E., Condron, L. M., Oberson, A., Sinaj, S., and Fardeau, J. C. 2000. Processes governing phosphorus availability in temperate soils. Journal of Environmental Quality 29: 15-23.

[11] Karltun, E., Mulugeta Lemenih and Motuma Tolera. 2013. Comparing Farmers' Perception of Soil Fertility Change with Soil Properties and Crop Performance in Beseku, Ethiopia. Land degradation and development, 24: 228-235.

[12] Regassa, H. and Agegnehu, G. 2011. "Potentials and limitations of acid soils in highlands of Ethiopia: A review." In Barley research and development in Ethiopia edited by B. Mulatu and S. Grando, 103-112. ICARDA, Aleppo, Syria. 
[13] Roy, R. N., Finck, A., Blair, G. J, and Tandon, H. 2006. Plant nutrition for food security. A guide for integrated nutrient management. FAO Fertilizer and Plant Nutrition Bulletin 16: 368.

[14] Scoones, I. and Toulmin, C., 1999. Policies for soil fertility management in Africa. Policies for soil fertility management in Africa.

[15] SAS (Statistical Analysis System) Institute. 2004. SAS/STAT user's guide. Proprietary software version 9.00. SAS Institute, Inc., Cary, NC.

[16] Taffesse A. S, Dorosh. P, Asrat. S, 2011. Crop Production in
Ethiopia: Regional Patterns and Trends. Development Strategy and Governance Division, International Food Policy Research Institute, Ethiopia Strategy Support Program II, Working Paper No. 0016.

[17] Tekalign T. 1991. Soil, plant, water, fertilizer, animal manure and compost analysis. Working Document No. 13. International Livestock Research Center for Africa, Addis Ababa.

[18] Zeleke, G., G. Agegnehu, D. Abera and S. Rashid, 2010. Fertilizer and soil fertility potential in Ethiopia: Constraints and opportunities for enhancing the system. Washington, DC: IFPRI. 